\title{
骨密度情報に基づく $\mathbf{X}$ 線透過シミュレーションによる 生体関節動態解析手法の開発*
}

\author{
日 垣秀彦*1, 白石善 孝*2,下戸 健*1 \\ 中西義 孝*3, 三浦 裕 正*4, 岩 本 幸 英*4

\begin{abstract}
Development of Motion Analytic Technique in vivo for the Natural Joint by Simulation of $\mathrm{X}$-ray Transmission Based on Bone Density Distribution
\end{abstract}

\author{
Hidehiko HIGAKI*5, Yoshitaka SHIRAISHI, Takeshi SHIMOTO, \\ Yoshitaka NAKANISHI, Hiromasa MIURA and Yukihide IWAMOTO \\ ${ }^{* 5}$ Department of Biorobotics, Faculty of Engineering, Kyushu Sangyo University, \\ 2-3-1 Matsukadai, Higashi-ku, Fukuoka-shi, Fukuoka, 813-8503 Japan
}

\begin{abstract}
For the operative method and evaluation of patients, it is important to clarify three-dimensional kinematics of the natural joint. The study aimed to develop a three-dimensional motion analysis for natural knee joints in vivo, using an image matching technique with a high-resolution flat panel detector (FPD). Technique was semi-automatically performed by superimposing the three-dimensional gray-scale model that was reconstructed in beforehand computer on the actual $\mathrm{X}$-ray images. Three-dimensional gray-scale model of the natural knee joint were reconstructed using computed tomography (CT) data. The reconstructed image was moved on a computer so that it could be matched to actual X-ray images. However, the number of pixels in a whole reconstructed image was so huge. Therefore, in this study, several small windows were set up, in which a region of interest was determined to calculate instead of viewing the whole region of the image. The accuracy of the motion analytic method for the natural knee joint was confirmed using some $\mathrm{X}$-ray images taken experimentally. High correlation was observed between the $\mathrm{X}$-ray images and the computational simulating image. The motion analytic method we proposed was a very useful tool for measuring the six-degree-of-freedom (6-DOF) motion of natural kness in vivo.
\end{abstract}

Key Words: Biomechanics, Medical Engineering, Image Processing, Computer Simulating Method, Natural Knee Joint, 6-DOF Motion Analysis

1. 精

in vivo バイオメカニクスの領域において，人工関節 の動態パターンの特定や摩耗問題等の解明を行うため, 全人工膝関節置換術（Total knee arthroplasty, TKA）後

\footnotetext{
* 原稿受付 2009 年 1 月 5 日.

*1 正員, 九州産業大学工学部バイオロボティクス学科(画 8138503 福岡市東区松香台 2-3-1).

*2 正員, 九州産業大学大学院工学研究科.

*3 正員, 熊本大学大学院自然科学研究科産業創造工学専攻先端 機械システム講座 (丞 860-8555 熊本市黒髪 2-39-1).

*4 九州大学医学研究院 (画 812-8582 福岡市東区馬出 3-1-1).

E-mail : higaki@ip.kyusan-u.ac.jp
}

の生体内における人工関節の動態について盛んに議論 が行われるようになっている ${ }^{(1) \sim(3)}$. 本研究グループ でも全人工関節置換膝を対象とした 6 自由度動態解析 を行っており ${ }^{(4)}$, これらの研究により人工関節の改良 や設計がなされ，生活の質 (Quality of life,QOL) の向 上が期待されている. これに加え, 生体関節の動態を 明らかにすることで, 種々の関節疾患の診断や，人工 関節およひ術式の改良など様々な分野において，有用 な情報を与えることができる. そのため, 生体関節を 対象とした動態解析手法が求められている.

生体関節を対象とした動態解析手法は，人工関節を 対象とした動態解析手法を応用することで開発できる と考えられる. しかし，生体関節を対象とした場合， 
骨の輪郭を利用した動態解析では，X 線画像から正確 な骨形状を抽出する 2 值化処理が議論されている ${ }^{(5)}$. 骨形状の輸郭を用いた手法においては，X線画像に対 L, CT (Computed tomography) ¿ MRI (Magnetic resonance imaging) それぞれから作成した 3 次元モデル を使用した手法例も挙げられているが，精度検定にお いて，整形外科領域で有効とされている平均誤差 1.0 $\mathrm{mm}, 1.0 \mathrm{deg}$ 以内を超えている変位も確認できる ${ }^{(6)}$. さらに，特殊な植込み機器を用いた解析例も報告され ているがの，侵撉の問題があるため生体での検証は憚 られている. そのため, 生体関節における運動メカ二 ズムの評価方法は確立されておらず，十分な動態解析 が行われていない現状がある.

そこで本研究では，人工膝関節を対象とした本研究 グループの動態解析手法を応用し，CT 画像から作成 した投影シミュレーション像と，フラットパネルディ テクター（Flat panel detector, FPD）から得られるX 線 動画像の各ピクセルにおける画素值の画像相関を用い ることで, 生体関節の正確な 6 自由度運動を計測する 手法を開発し，その有用性について検討した。

\section{2. 対电およひ方法}

2-1 対象の撮影に使用した CT と FPD を図 1 に示す. CT 撮影では, スライス画像デー タ $(512 \times 512 \mathrm{pixel}$, スライス厚さ $1.0 \mathrm{~mm}, \mathrm{DICOM}$ 規格 データ）が取得でき，骨密度等の情報を含んだグレ一 スケール 3 次元モデルの構築に用いる. CT 撮影から 得られるスライス画像データは, 歪みの少ない画像デ 一タとして取得することができる. CT の撮影方法と しては, ダイナミック CT と呼ばれる投影剂を注入し て撮影する方法等があるが，本研究では生体関節の骨 密度等の情報を含んだスライス画像デ一タの取得が目 的であるため, 造影剤を使用せずに撮影を行う単純 CT で撮影を行った．FPD 撮影では，X 線動画像データ （2046×1536 pixel, DICOM 規格データ）が取得でき， 解析対象の動態を連続撮影することができる. 従来の

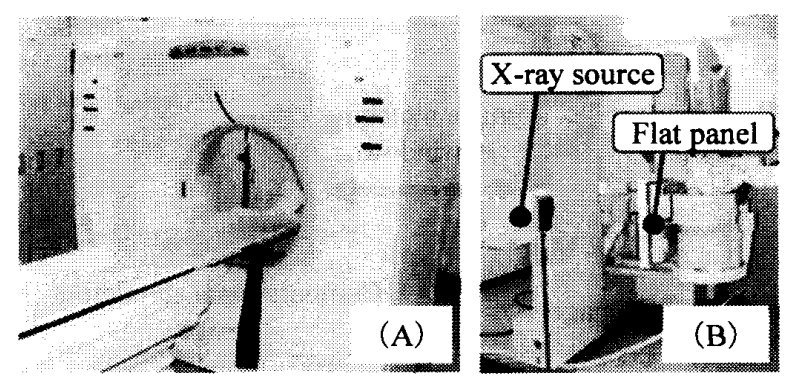

Fig. 1 Imaging devices (A) Computed tomography (B) Flat panel detector
Image intensifier での撮影では，X線入力面が曲面であ るためX線画像辺縁部に歪みが発生し, 歪みを補正す る必要がある，しかし，FPDを利用した撮影において は，平面センサー（Flat panel）を用いているため, 得 られた X 線動画像データは, 歪みのない画像を取得す ることができる.

\section{2-2 投气シミュレーション鮴の作成 取得した} CT 画像を図 2 のように順番に並べることによって, 骨密度等の情報を含んだ対象のグレースケール 3 次元 モデルを構築した。

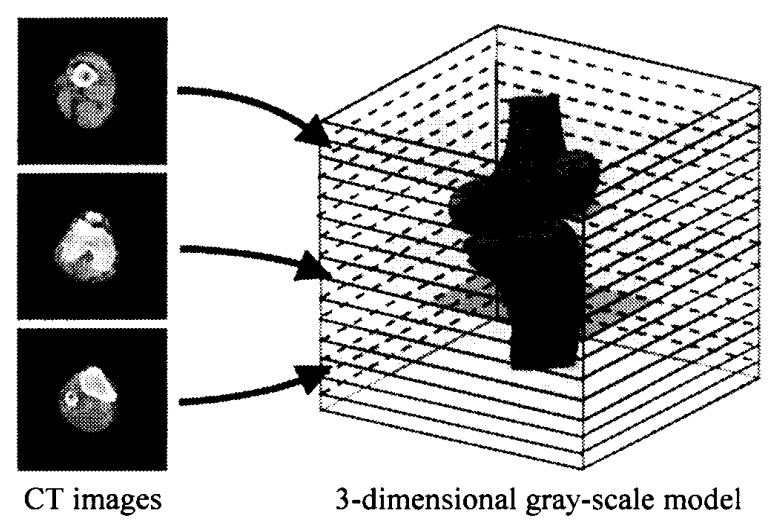

Fig. 2 The three-dimensional gray-scale model reconstructed using computed tomography images

グレースケール 3 次元モデルは, $0.351 \times 0.351 \times 1.0$ mm のボクセル (Volume cell, voxel) で構成される.こ のグレースケール 3 次元モデルをコンピュータ上で任 意の空間に配置し, 光源およひ投影面を X 線撮影時と 同様の条件とすることで, 6 自由度に変化することが できる投影シミュレーション像の作成を行う（図3）。 ワールド座標系の定義は投影面上の左上端点を原点と し, 水平方向に $\mathrm{X}$ 軸, 垂直方向に $\mathrm{Y}$ 軸, 法線方向に $\mathrm{Z}$ 軸とした. グレースケール 3 次元モデルの座標系の定 義は，任意に定めた。光源と投影面の相対関係は，座 標系構築フレーム（Coordinate building frame）を用い, $\mathrm{X}$ 線源と平面センサーの相対関係を求めた值を適用し た (8).

投影シミュレーション像作成における各ピクセルの シミュレーション值は, 光源座標を $O\left(x_{0}, y_{0}, z_{0}\right)$, 投 影面上の任意の点を $A(x, y)$ とし，仮想 X 線がグレ一 スケール 3 次元モデル内を通過する距離と骨密度等の 情報值であるボクセル值により算出を行った，図 3 に 示すように 1 つボクセルに着目した場合, 仮想 X 線 は直線ベクトルであるため, ボクセルを通過しない場 合を除き, ボクセルの領域内に必ず 1 つ，もしくは2 
つの交点 $P_{i}$ が得られる. 仮想 $\mathrm{X}$ 線がボクセル内を通過 する場合, 仮想 X 線が通過する 2 点間距離 $L$ を算出し た. ボクセルの頂点を $\left(x_{i}, y_{i}, z_{i}\right)$ ，それを交点とし直 交するボクセルの 2 辺をべクトル $\vec{a}_{i}, \vec{b}_{i}$ とすると， ボクセルの6つの平面 $\left\{\left(x_{i}, y_{i}, z_{i}\right), \vec{a}_{i}, \vec{b}_{i}\right\} \quad i=1 \sim 6$ と 仮想 X 線 $\overrightarrow{O A}$ との交点 $P_{i}\left(x_{i}^{\prime}, y_{i}^{\prime}, z_{i}^{\prime}\right) \quad i=1 \sim 6$ は, 式

（1）を満たすかどうかで求めることができる.

$$
\begin{aligned}
& P_{i}=\left(x_{i}, y_{i}, z_{i}\right)+t \vec{a}_{i}+s \vec{b}_{i} \\
& i=1 \sim 6,0 \leqq t \leqq 1,0 \leqq s \leqq 1
\end{aligned}
$$

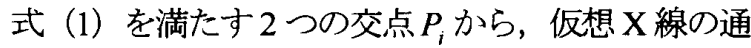
過距離 $L$ を算出する.このとき，交点 $P_{i}$ が 1 つ以下な ら $L=0$ とした. 求められた仮想 X 線の通過距離 $L に$ ボクセル值 $\alpha(x, y, z)$ を乗じ, $\mathrm{X}$ 線吸収量とした. これ を全てのボクセルに適用させることにより，投影面上 に出力される点 $A(x, y)$ のシミュレーション值を求め た（式（2））.

$$
A(x, y)=\sum_{n} \alpha_{n} L_{n}
$$

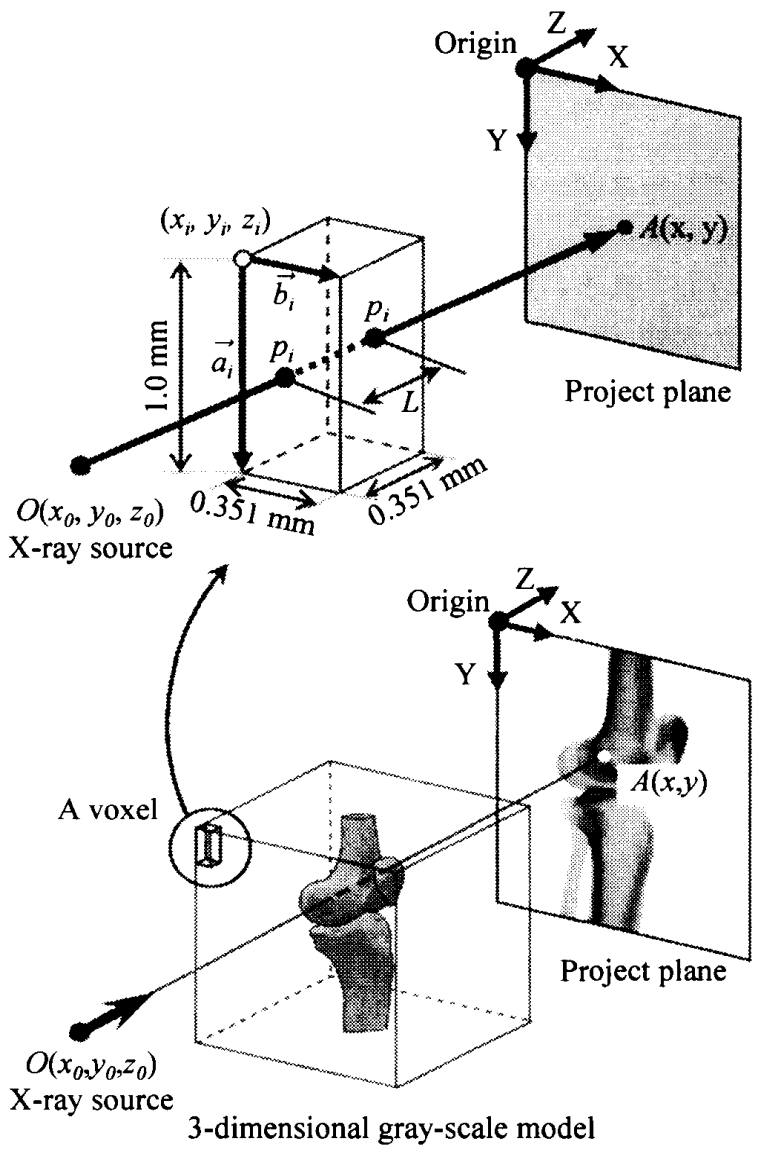

Fig. 3 Process of calculation in computational simulating image
$2 \cdot 3$ 動態解析手法は, $2 \cdot 2$ 節で 述べた投影シミュレーション像を用い，解析対象とな るX線動画像と投影シミュレーション像の各ピクセル における画素值の画像相関を用いたイメージマッチン グを行うことで，生体関節の動態解析を行う.

この際，X線動画像では，対象の動作により皮膚や 靬帯等の軟部組織が変形し，イメージマッチング中の ノイズとなるため, 変形が小さい骨部に複数のウィン ドウを設けて解析を行う。しかし，相関係数が最大と なる極值が走查範囲内で多数存在することが予想され るため，解析を 2 段階に分けた 2 段階推定手法を用い た.

第 1 段階では，図4（A）に示すように，大まかな空 間位置と姿勢の推定を行うため，必要とする骨全体を ウィンドウで囲み対象とし，X 線動画像と投影シミュ レーション像のウィンドウ内画素数を減じて解析を行 った. まず, 1/64に減じたものに対しイメージマッチ ングを行い，空間位置と姿勢の推定を行う。次に，得 られた空間位置と姿勢を初期值にし，1/16に减じたも のに対しイメージマッチングを行うことで，第 1 段階 の空間位置と姿勢を推定した.

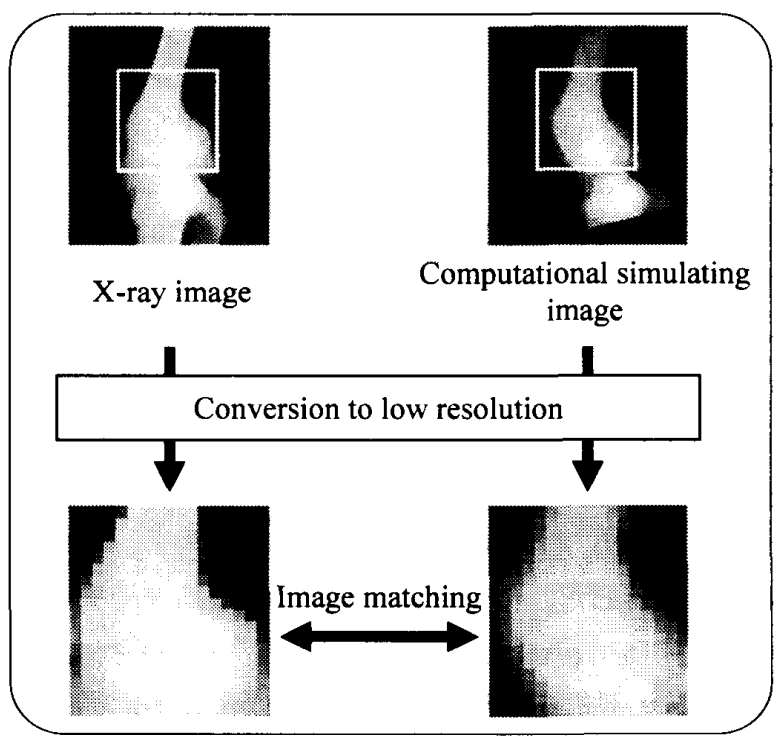

(A) First step

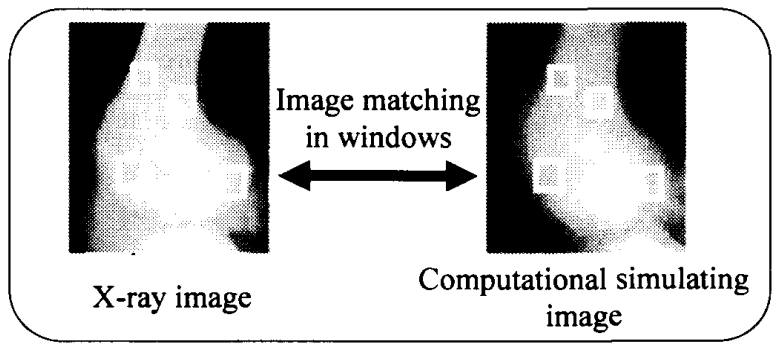

(B) Second step

Fig. 4 Process of image matching method 
第2段階では, 図4 (B) に示すように, 第 1 段階で 得られた空間位置と姿勢を初期値に，ウィンドウ内画 素数を減じず詳細なイメージマッチングを行う。この 際，膨大なデータ処理が必要なため解析時間を考慮し， 対象の空間位置と姿勢を鋭敏に反映しえる骨情報が多 く含まれる部位に複数のウィンドウを任意に設け，イ メージマッチングを行った. ここで得られた結果を, 解析対象の最終的な空間位置と姿勢とした.

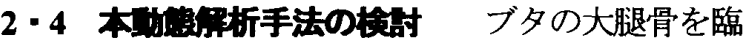
床応用の際と同様な条件でほぼ真横から FPD 撮影し, 得られたX線動画像に対し投影シミュレーション像を それぞれの自由度に変化させ，投影シミュレーション 像が示寸分解能について検討した（図 5）。まず，対 象の空間位置と姿勢を鋭敏に反映しえる骨情報が多く 含まれる部位に複数のウィンドウを任意に設け，X線 動画像と投影シミュレーション像の相関係数が最も高 くなる 6 自由度を推定し，このときのグレースケール 3 次元モデルの空間位置および姿勢を基準位置とした。 この基淮位置から，グレースケール 3 次元モデルを投 影面に対し水平方向である $\mathrm{X}, \mathrm{Y}$ 軸方向と, 法線方向 であるZ軸方向に基準位置からそれぞれ-1.0 mm から $1.0 \mathrm{~mm}$ まで $0.2 \mathrm{~mm}$ 刻みで並進運動させた. 同様に, 回転運動においても各軸に対し-1.0 deg から $1.0 \mathrm{deg} ま$ で $0.2 \mathrm{deg}$ 刻みで変位させ,イメージマッチングにおけ る相関係数の変化について検討を行った.

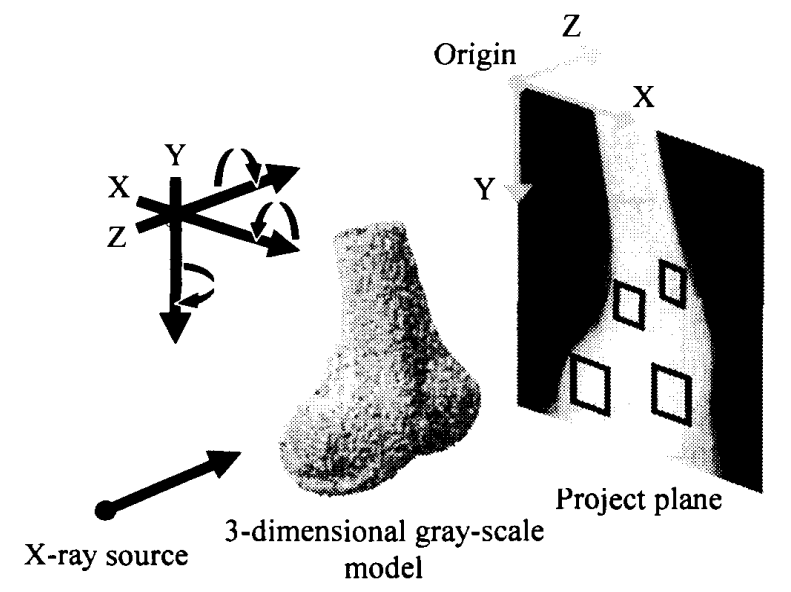

Fig. 5 Examination of resolution indicated by computational simulating image

次に, $2 \cdot 3$ 節で示した 2 段階推定手法の有用性を確 認するため, ブタの大腿骨を使用した動態解析シミュ レーションを行い, イメージマッチングの各推定段階 にお引ける相関係数に基づく 6 自由度の変化の過程につ いて検討した.
最後に，本動態解析手法の精度検定を行うため，動 態解析シミュレーションを行った。ブタの大腿骨を臨 床応用の際と同様な条件でほぼ真横から FPD 撮影し たものを初期姿勢とした. 図6に示すように初期姿勢 から FPD の平面センサーに対し，おおよそ水平方向と 法線方向に 0.5，1.0，2.0，5.0，10.0 mm 並進運動，絶 対座標系の各軸に重ならない任意の軸を中心に，0.5， 1.0，2.0，5.0，10.0 deg 回転運動を与えて行い，それぞ れに対し X 線撮影を行った.これらすべての X 線動画 像に対してイメージマッチングすることで，それぞれ の変位方向に対して, 上記 5 条件を各 3 回の計 15 回ず つ繰り返し検定を行い，二乗平均平方根偏差（Root mean square error, RMSE）を使用し精度を算出した.

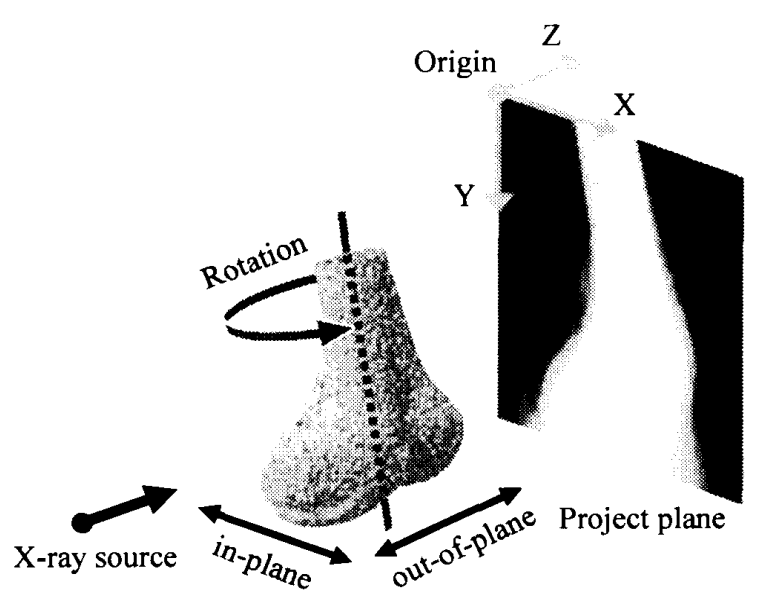

3-dimensional gray-scale model

Fig. 6 Condition of X-ray photography in accuracy test

\section{3. 鼓果}

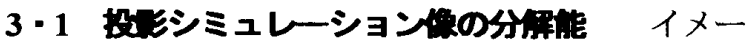
ジマッチングにおける並進運動と回転運動の変位に対 する相関係数の変化を図 7 に示す，基隻位置となる 6 自由度では，X線動画像と投影シミュレーション像の 相関係数は約 0.897 と高い值を示していた。

グレースケール 3 次元モデルを基隻位置から各軸方 向に並進運動させた場合，全自由度において相関係数 が減少することが確認できた．投影面に対し水平方向 である X軸方向の変位では, 他の自由度と比較し相関 俰数が大きく減少しており，変位量-1.0 mm で相関係 数が最低の約 0.850 を示した. 投影面に対し水平方向 である Y 軸方向の変位では，基準位置から変位するに つれ相関倸数は減少しており, 変位量 $1.0 \mathrm{~mm}$ で相関 係数が最低の約 0.882 を示した. 投影面に対し法線方 向である Z 軸方向の変位では，基準位置から変位する 
につれ相関倸数は僅かに減少しており, 変位量 $1.0 \mathrm{~mm}$ で最低の約 0.896 を示した。

グレースケール 3 次元モデルを基準位置から各軸を 中心に回転軍動させた場合, 並進運動させた際と同様, 回転させるに従い全自由度において相関保数の減少が 確認されたが，変化は小さかった．X軸回りの回転運 動では，基淮位置から変位させていくと相関係数は全 体的に緩やか汇減少しており, 変位量 $1.0 \mathrm{deg}$ で相関保 数が最低の約 0.894 を示した. Y 軸回りの回転䡣動で は, 変位量- $1.0 \mathrm{deg}$ で相関係数が最低の約 0.889 となっ た. Z 軸回りの回転運動では，変位量 $1.0 \mathrm{deg}$ で相関係 数が最低の約 0.885 となった.

並進運動と回転運動の全自由度において, 自由度に 対して相関係数の変化に差が見られたが, $0.2 \mathrm{~mm}, 0.2$ degの僅かな変位でも，相関係数の減少を確認できた。
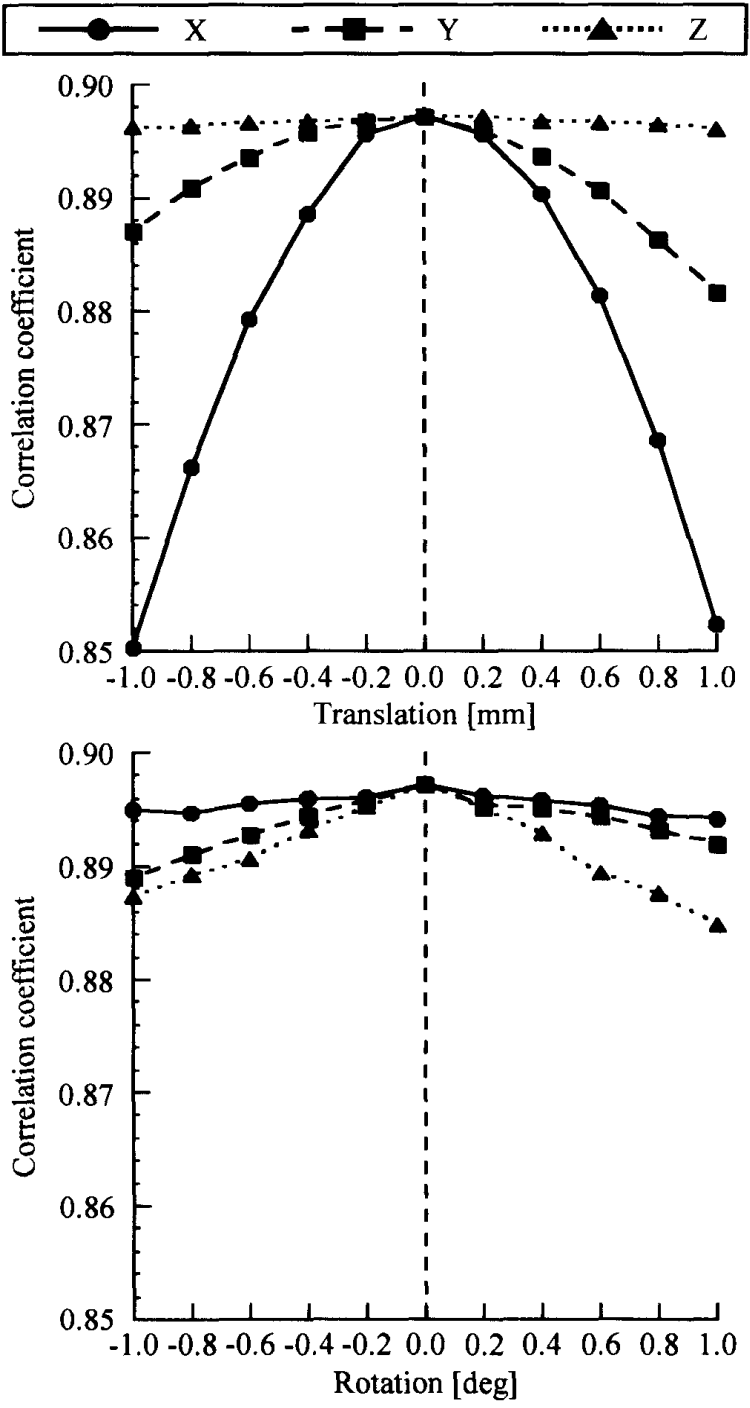

Fig. 7 Change of correlation coefficients during 6DOF motion of computational simulating image in image matching
3.22 段煋推定手法の检㣙 2 段階推定手法の 各段階推定結果における，各軸の並進運動と回転運動 に対する相関係数の過程を図8, 図 9 およひ図 10 に示 す，図中の白点は，各段階における空間位置と姿勢を 示している.

図 8 は，解析を行う前の初期姿勢においての相関係 数を示している. 本検定で行った走査範囲においては, $\mathrm{X}, \mathrm{Z}$ 軸では相関係数が最大となる極值が 1 箅所だが,
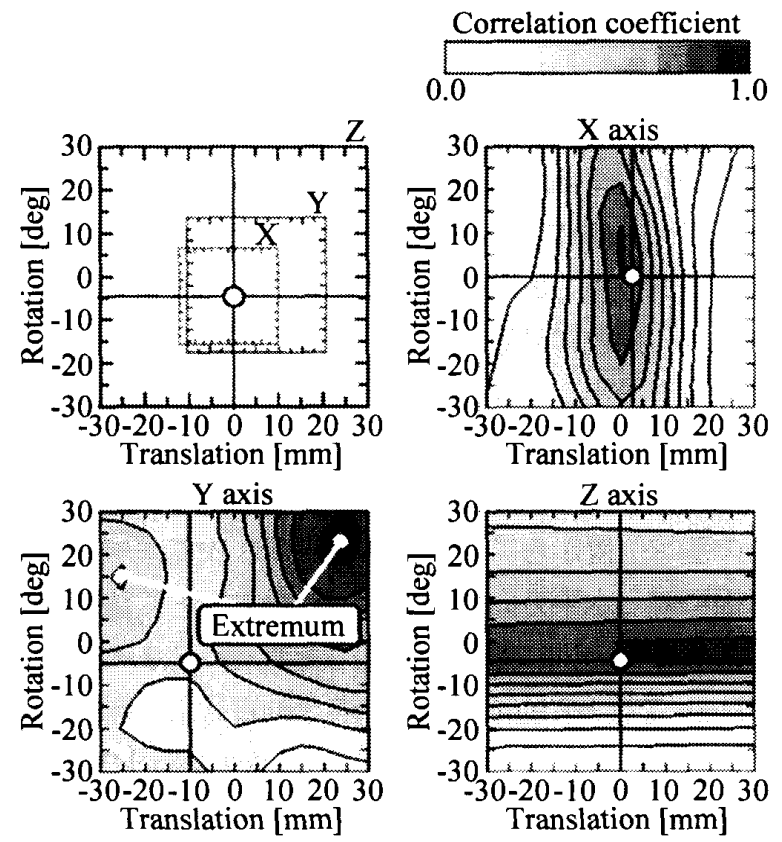

Fig. 8 Default position of translation and rotation with respect to correlation coefficients
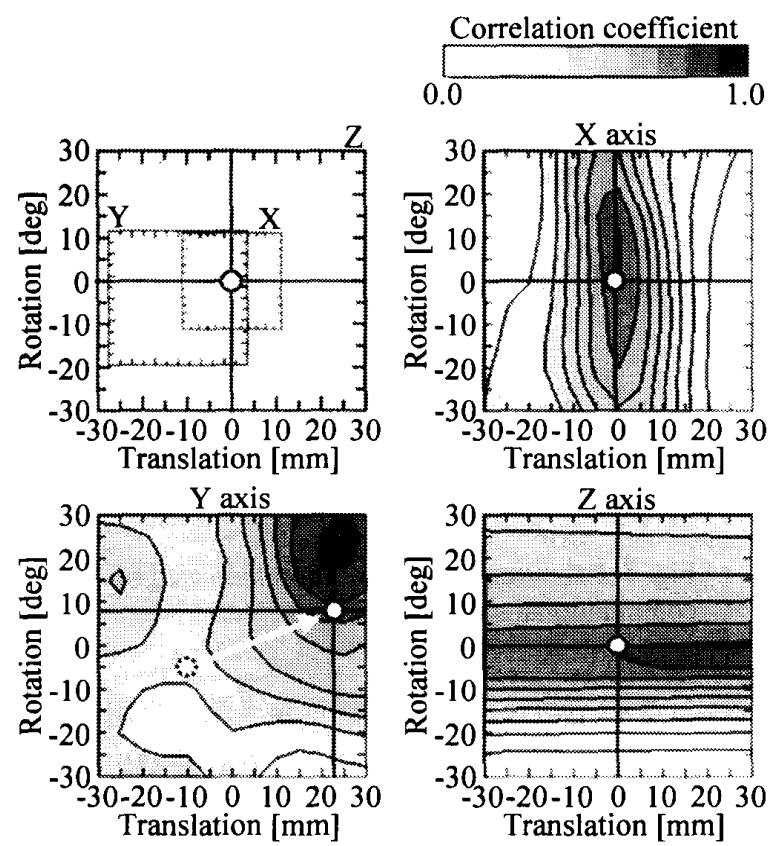

Fig. 9 Position in first step of translation and rotation with respect to correlation coefficients 


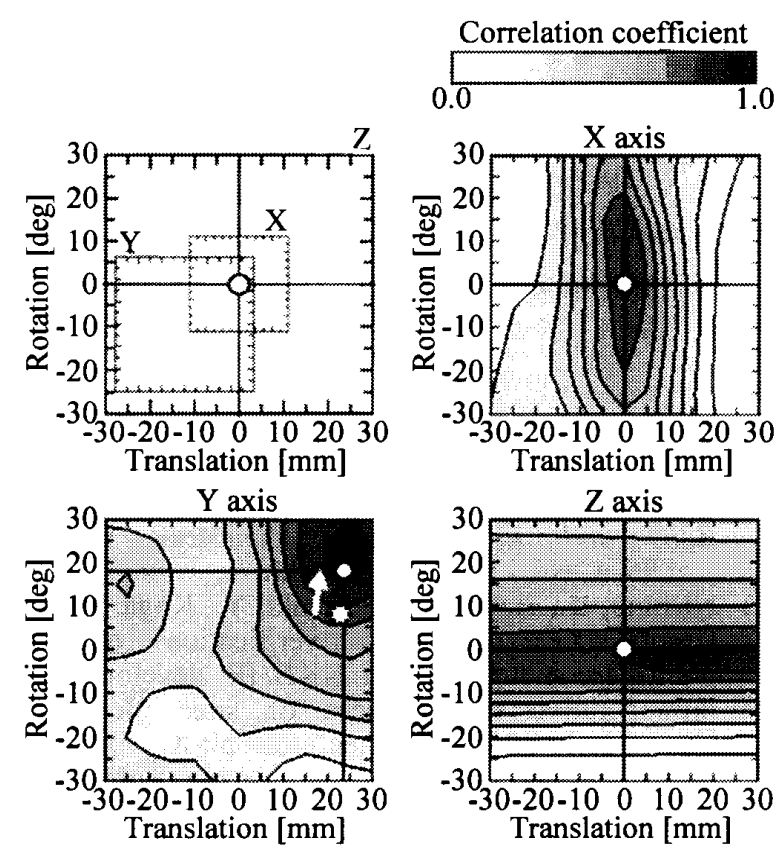

Fig. 10 Position in second step of translation and rotation with respect to correlation coefficients

Y 軸では極值が 2 箅所あることが確認できる.このこ とから，Y 軸ではどちらの極值にも収束する可能性が 考えられる.

しかし，第 1 段階における大まかな空間位置と姿勢 の推定を行った結果では，誤った極值側を回避し，正 しい極值側一収束していることが確認できる(図 9).

さらに，第 2 段階の詳細な空間位置と姿勢の推定を 行った結果では，正しい極值側でより大きな相関係数 へ収束していることが確認できる（図 10）。よって, 本研究で用いた 2 段階推定手法は, 正しい極值への収 束に有用な手法であると考えられる.

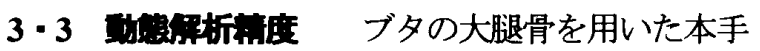
法の精度検定の結果を表 1 およひ淐 11 に示す.並進運 動におけるおおよそ水平方向の変位の平均誤差は 0.84 $\mathrm{mm}$ であり, 初期姿勢力ら $10.0 \mathrm{~mm}$ の変位で最大誤差 $1.61 \pm 0.41 \mathrm{~mm}$ を生じた. おおよそ法楾方向の変位の 平均誤差は $0.17 \mathrm{~mm}$ であり，初期姿勢から $10.0 \mathrm{~mm}$ の 変位で最大誤差 $0.18 \pm 0.07 \mathrm{~mm}$ を示した. 任意の軸を 中心に行った回転運動における平均誤差は $0.29 \mathrm{deg}$ で あり, 初期姿勢から $2.0 \mathrm{deg}$ の変位で最大誤差 $0.35 \pm$ $0.26 \mathrm{deg}$ を生じた.

Table 1 Error of image matching method using femur Average error (RMSE)

\begin{tabular}{ccc}
\hline \multicolumn{2}{c}{ Translation } & Rotation \\
(in-plane) & (out-of-plane) & \\
\hline $0.84[\mathrm{~mm}]$ & $0.17[\mathrm{~mm}]$ & $0.29[\mathrm{deg}]$
\end{tabular}
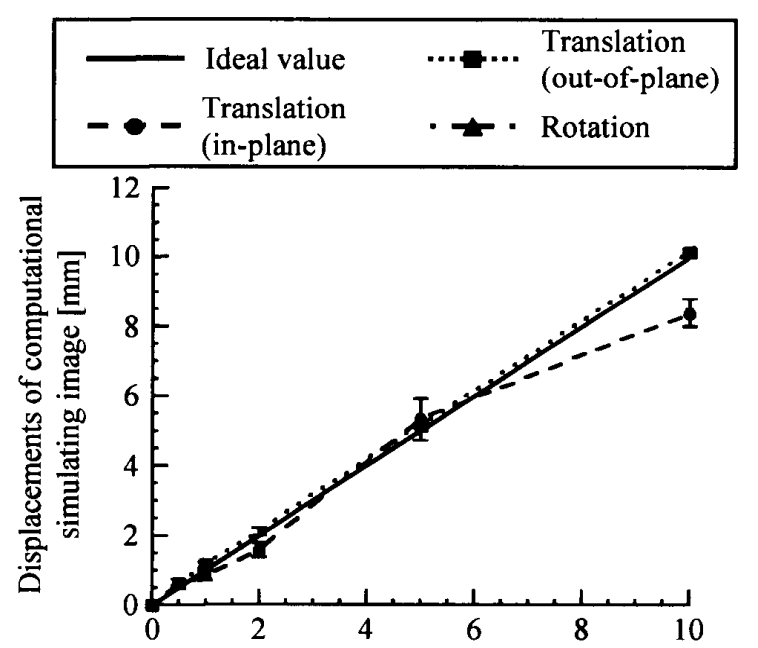

Translations from femoral default position [mm]

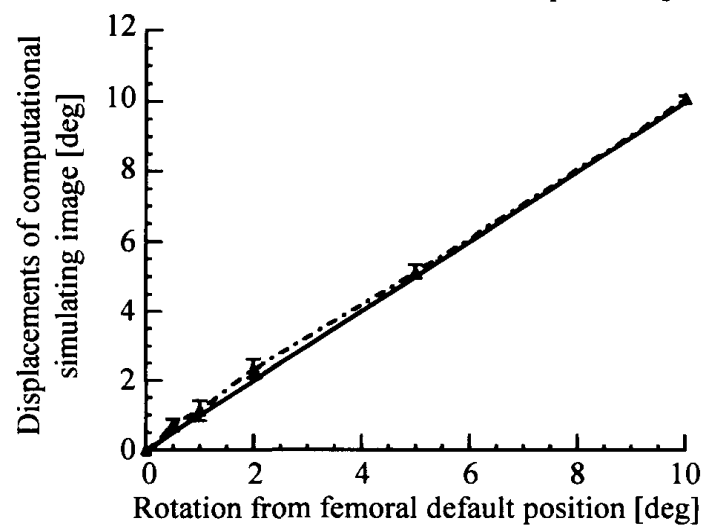

Fig. 11 Error of image matching method using femur

\section{4. 考宗}

投影シミュレーション像の分解能については, 並進 運動における相関係数の変化を示寸結果において, $\mathrm{X}$ 軸方向と $\mathrm{Y}$ 軸方向の変位では, $\mathrm{X}$ 軸方向の変位の方が $\mathrm{Y}$ 軸方向の変位に対して，大きく相関倸数が減少して いた。 これは，異方性を持ったボクセルが，投影面に 対してY軸方向に縦長で構成されている. さらに, 本 検定では, FPD の撮影時に骨軸が Y 軸方向になるよう に撮影を行っているため, 皮質骨や海綿骨等が Y 軸方 向に比較的強い配向を示していることが考えられる. そのため, X 軸方向の変位の方が, $\mathrm{X}$ 線動画像に対し 投影シミュレーション像の変化が大きくなり, 相関係 数の変化が大きくなったと考えられる. Z 軸方向の変 位では，投影面に対し法線方向の変位であり，投影シ ミュレーション像のスケーリングにあたる.そのため, 若干の変位量では大きな変化は見られなかったと考え られる.

回転運動における相関係数の変化を示す結果におい ては, $Z$ 軸回りの回転軍動で相関係数に最も大きな変 化が確認できた. これは, $\mathrm{Z}$ 軸回りの回転運動が屈曲・ 
伸展の変位に相当するため, 大腿骨幹のずれからも顕 著に変化が現れたと考えられる.X軸と Y 軸回りの回 転軍動は，それぞれ内転・外転と内旋・外旋の運動に 相当するが，ウィンドウは大腿骨顆部に設けられてお り, 本実験ではZZ軸回りの回転軍動ほど変化しなかっ たと考えられる.

並進運動と回転運動の全自由度において，0.2 mm, $0.2 \mathrm{deg}$ の僅かな変位でも相関倸数の減少を確認でき たことから， $0.2 \mathrm{~mm}, 0.2 \mathrm{deg}$ 以内の分解能を持ってい ることが言え, 複数のウィンドウ内のみでの画像相関 を利用したイメージマッチング手法の有用性を示唆し ていることが考えられる.

本動態解析手法の精度については，並進運動におい て, 法線方向の変位に対する X 線動画像の変化は微小 なため, 水平方向の変位より精度が劣ると考えられる が, 本検定では水平方向の変位の方が, 法線方向の変 位に比べ精度が劣っていた，その理由として，FPDの 光源が一定の微小面積を有していることが考えられる. しかし，投影シミュレーション像の作成においては， 仮想の光源を点光源として用いている. そのため, 面 内方向の変位にあたる水平方向の変位では，投影シミ ユレーション像の作成時に, 光源の誤差による影響を 大きく受け, 面外方向の変位にあたる法線方向の変位 に比へ，精度が劣ったと考えられる.

すべての変位において，平均誤差が整形外科領域で 有効とされる $1.0 \mathrm{~mm}, 1.0 \mathrm{deg}$ 以内に収まっているため, 生体関節の動態解析手法として有用性があると考えら れる。

\section{5. 站}

生体関節の正確な 6 自由度運動を計測するため, CT 画像データを基に作成した投影シミュレーション像と X 線動画像データを用いることで, 各ピクセルにおけ る画素值の画像相関を利用した本動態解析手法につい て検討を行った. 投影シミュレーション像の分解能に おける検討では, $0.2 \mathrm{~mm}, 0.2 \mathrm{deg}$ 以内の分解能がある ことが確認でき, 複数のウィンドウ内のみでの画像相 関を利用した本動態解析手法の有用性を示唆している ことが考えられる. 2 段階推定手法は誤った極值を回 避し， 正しい極值へ収束させるのに有用であることが 確認できた. 本手法の動態解析における精度検定では, 整形外科領域で有効とされる平均誤差が $1.0 \mathrm{~mm}, 1.0$ deg 以内に収まっていることが確認できた，以上のこ とより，本手法の生体関節を対象とした正確な 6 自由 度動態解析手法は, 有用であると考えられる.しかし, 1 つの X 線画像を解析するにあたり, 本手法の解析時 間は 6 時間程度を要しているため, 臨床応用時におい ては検討が必要であると考えられる.

\section{文莿}

(1) Banks, S.A., Harman, M.K., Bellemans, J. and Hodge, W.A., Making Sense of Knee Arthroplasty Kinematics: News You Can Use, The Journal of Bone and Joint Surgery. American volume, Vol.85-A, No.4 (2003), pp.64-72.

(2) Nishino, K., Hayashi, T., Suzuki, Y., Koga, Y. and Omori, G., Accuracy verification of the photostereometric system $\mathrm{KKN} / 1 \mathrm{~B}$ developed for intraoperative measurement of knee movement immediately after total knee arthroplasty, Frontiers of Medical and Biological Engineering, Vol.9, No.4 (1999), pp.261-273.

(3) Walker, S.A., Hoff, W., Komistek, R. and Dennis, D., "In vivo" pose estimation of artificial knee implants using computer vision, Biomedical sciences instrumentation, Vol.32, (1996), pp.143-150.

(4) Shimoto, T., Higaki, H., Yasutake, S., Yoshizumi, M., Nakanishi, Y., Hamai, S., Miura, H. and Iwamoto, Y., Motion Analysis of Kneeling for Artificial Knee Implants, Biomechanism, Vol.18, (2006), pp.71-78.

(5) Nishimura, I., Ishida, T., Murabayashi, S., Mitamura, Y., Nakamura, T., Ito, H., Matsuno, T., Higa, M., Hasei, M. and Kuramoto, K., A Study of Outline Sampling Strategies for the Femoral CT Images, Transactions of the Japanese Society for Medical and Biological Engineering, Vol.44, No.1 (2006), pp.77-84.

(6) Moro-oka, T., Hamai, S., Miura, H., Shimoto, T., Higaki, H., Fregly, B.J., Iwamoto, Y. and Banks, S.A., Can Magnetic Resonance Imaging-Derived Bone Models $\mathrm{Be}$ Used for Accurate Motion Measurement with Single-Plane Three-Dimensional Shape Registration?, Journal of Orthopaedic Research, Vol.25, No.7 (2007), pp.867-872.

(7) Lafortune, M.A., Cavanagh, P.R., Sommer, H.J. and Kalenak, A., Three-dimensional kinematics of the human knee during walking, Journal of Biomechanical Engineering, Vol.25, No.4 (1992), pp.347-357.

(8) Higaki, H., Shimoto, T., Miura, H., Kawano, T., Mawatari, T., Moro-oka, T., Nakanishi, Y., Kurata, $\mathrm{K}$. and Iwamoto, Y., Application of Pattern Matching Method in Motion Analysis for TKA, Transactions of the Japan Society of Mechanical Engineers, Series C, Vol.68, No.674 (2002), pp.221-228. 